\title{
Economic Value of Mangrove Forest Ecosystem Damage in Ambon Baguala District Ambon Maluku Indonesia
}

\author{
Revalda Amanda Yacoba Bribka Salakory ${ }^{1}$, Nuddin Harahab², Bagyo Yanuwiadi ${ }^{3}$ \\ ${ }^{1}$ Post Graduate School of Environmental and Development, Graduate, Program, Brawijaya University \\ ${ }^{2}$ Department of Social Economics, Faculty of Fisheries and Marine Sciences, Brawijaya University \\ ${ }^{3}$ Department of Biology, Faculty of Mathematics and Natural Sciences, Brawijaya University
}

\begin{abstract}
This study aims to analyze the level of damage and estimate the economic value of mangrove forest ecosystem damage in Teluk Ambon Baguala District. Data were collected through interviews, documentation, and observation. Method analysis employed was Vegetation Index or NDVI (Normalized Difference Vegetation Index) and economic valuation of damage impact. The result showed that Mangrove forests in Teluk Ambon Baguala district on 2015 were categorized 'not damaged' $(17.24 \mathrm{Ha}$ ) and 'lightly damaged' (34.76 Ha). Overall, the economic value of ecosystem services lost due to mangrove forest destruction by water pollution in Teluk Ambon Baguala district. The lost value approximately reached Rp. 3.808.594.100 per year, with the following description: Negeri Passo for Rp. 3,765,838,300 per year, Negeri Lama Village for Rp. 945.627 .800 per year and Nania Village for Rp. 650,750,400 per year. A Pigovian taxes were suggested in supporting the conservation of mangrove forest ecosystems and control pollution in Ambon Bay waters.
\end{abstract}

Keyword: Damage, Economic value, Ecosystem, Mangrove forest

\section{INTRODUCTION}

Mangrove is a forest ecosystem located in the intertidal zone between tropical and sub-tropical regions [1]. Mangrove forests are considered as one of the most productive ecosystems in the world, as they provide environmental services for other living creatures in the surrounding area: (a) as a nursery ground, fishing ground and feeding ground for sea creatures such as fish, crabs, reptiles, etc. (B) feed for livestock, (c) raw materials for traditional medicines (d) shoreline protectors from coastal erosion and abrasion and (e) marine pollution controllers as well as (F) sediment catchers which came from construction activities on land [2]. Globally, about 150,000 $\mathrm{km} 2$ of mangrove forest is spread over 18 countries in the World including Indonesia. However, in the last three decades, Indonesia has lost $40 \%$ of mangroves due to various development activities such as conversion of mangrove forest land to farming areas, settlements and other physical development scattered throughout Indonesia [3].

In Teluk Ambon Baguala district, the mangrove area continues to decline annually. Based on the research conducted by Suyadi

\footnotetext{
Correspondence address:

Revalda Amanda Yacoba Bribka Salakory

Email : salakory.revalda29@yahoo.com

Address : Post Graduate School of Environmental and Development, Graduate, Program, Brawijaya University
}

(2009) from 1986 to 2001, it is found that mangrove area in Teluk Ambon Baguala decreased by $30.4 \mathrm{Ha}$ or $21 \%$ of the total area [4]. Madiama (2016) argued that the mangrove area continued to decline to $26.8 \%$ from the initial area of $41.955 \mathrm{Ha}$ or $10.6 \mathrm{Ha}$ within 9 years, from 2005 to 2014 [5]. The decline in mangrove area occurred as a result of conversion in coastal areas. Until 2013, there is conversion (transfer function) of mangrove region into development area in Teluk Ambon Baguala district equal to $34,01 \%$ out of $11.185,5 \mathrm{Ha}$. Most of the mangrove forest area in the center of the district have been converted to agricultural land, Settlement, national housing, and other physical development.

Recognizing the threatened existence of mangrove forest ecosystem, the Regional Government of Maluku Province and Ambon City conducted conservation by determining mangrove area in Teluk Ambon Baguala as a protected area based on Ambon City General Spatial Plan 2011 to 2021 and Provincial Regulation of Maluku Province no. 2 of 2007 and No. 16 of 2013, which regulates the preservation of mangrove forested coastal areas through efforts to protect the clearing of mangroves for other activities. Conservation's purpose to protect the economic value of coastal resources [6]. However, the conservation of mangrove ecosystems is often inconsistent with the economic valuation of ecosystem services [7]. Economic valuation is method to calculate a 
quantitative value of mangrove's ecosystem product and service [8]. One of the challenges in conserving mangrove ecosystems is the lack of knowledge about the economic value of ecosystem damage, which is one of the indicators in measuring the efficiency of natural resource and environmental management.

This study aims to analyze the level of damage and estimate the economic value of mangrove forest ecosystem destruction in Teluk Ambon Baguala district.

\section{RESEARCH METHOD}

This research is included in the type of quantitative research. Overall, data collection and analysis methods are described as follows:

\section{Data Collection Method}

Data were collected by employing the following methods:

1) Interviews with respondents based on questionnaires, to obtain data on respondent characteristics (including gender, age, education, number of family members and livelihoods), total economic value of mangrove forest ecosystems (including timber volume per $\mathrm{Ha}$, timber sale price, tree diameter average, tree height average, operational costs of timber harvesting; fish, shrimp, crab, oyster catch, bird eggs, etc. in mangrove forest, selling price and cost, total fish catches in waters around mangrove forest and operational costs) As well as internal factors (strengths and weaknesses) and external (opportunities and threats) in the conservation of mangrove forest ecosystems in Teluk Ambon Baguala district.

2) Documentation, to collect data on Landsat 8 ETM + Teluk Ambon Baguala 2015, downloaded from https://earthexplorer.usgs.gov. Mangrove potential and distribution as well as factors causing damage to mangrove forest ecosystem in Teluk Ambon Baguala district, policy Management of mangrove forest ecosystem in Ambon City, general condition of research location covering geographical and community socioeconomic condition, administration map and land cover in Teluk Ambon Baguala, obtained from related institution namely Ambon City Maritime and Fishery Office, the Regional Development Planning Agency of Ambon City, Ambon City BPS and Teluk Ambon Baguala District.

3) Observations made through field surveys of observed objects to test the accuracy of the vegetation index (NDVI).
For the economic value of mangrove forest destruction variable, the sample taken was 92 users of mangrove forest ecosystem services. This community consists of groups of fishermen, shells or crabs cultivators and pickers, as well as commodities selected at random (probability sampling). On the other hand, sample on mangrove forest conservation strategy variable is conservation policy stakeholders of mangrove forest in Teluk Ambon Baguala from several related institutions namely the Regional Development Planning Agency, Ambon City Research and Development (Bappeda Litbang), Ambon City Environment and Sewage Agency, Ambon City Fishery, Ambon Indonesian Institute of Sciences (LIPI), Environment and Natural Resources Research Center (PPLH / SDA) of Pattimura University, which are selected deliberately (non-probability sampling).

\section{Data Analysis}

Collected data were then analyzed using the following methods:

1) Vegetation Index or NDVI (Normalized Difference Vegetation Index) [9], calculated by the following equation:

NDVI $=\frac{N I R-r e d}{N I R+r e d}$

Criteria:

\begin{tabular}{cl}
\hline Index value & \multicolumn{1}{c}{ Density Category } \\
\hline $0,01-0,25$ & Sparse (Heavily damaged) \\
$0,25-0,50$ & Medium (Lightly damaged) \\
$0,50-1,00$ & Solid (Undamaged) \\
\hline
\end{tabular}

After obtaining the NDVI value, a precision test is performed to adjust the image interpretation results to the conditions in the field through a ground survey at some sample points using the following equation:

$$
\underset{\text { precision }}{\text { NDVI }}=\frac{\text { Correct total sample }}{\text { Total sample }} x 100 \%
$$

2) Total economic value of ecosystem service [10] estimated based on following formula:

\section{$T E V=D U V+I U V+O V+E V$}

\begin{tabular}{ll}
\hline TEV & $=$ Total economic value \\
DUV & $=$ Direct use value \\
IUV & $=$ Indirect use value \\
OV & $=$ Option use value \\
EV & $=$ Existence value
\end{tabular}


3) Economic value of ecosystem damage [11] estimated based on the following formula:

$$
\begin{aligned}
& \mathbf{R}_{\mathbf{t}}=\mathbf{N E T} \times \mathrm{L}_{\mathrm{A}} \\
& \mathrm{TC}=\sum_{1}^{10} \frac{R t}{(1+i) t}
\end{aligned}
$$

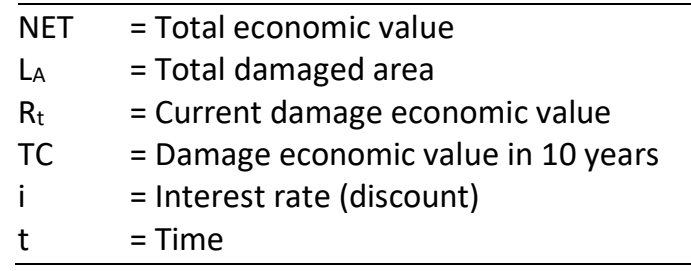

\section{RESULT AND DISCUSSION}

Mangrove Forest Ecosystem Damage in Teluk Ambon Baguala District

Damage to mangrove forest ecosystems was determined based on mangrove density values. It was analyzed using vegetation index or NDVI (normalized difference vegetation index). The NDVI value calculation is obtained from comparing infrared channel reflectance value close to visible light channel obtained from 458 Landsat imagery 8 ETM + acquisition imagery in June 2015, using ArcGIS 10.0 and ENVI 4.5 software.

Analysis result exhibits that NDVI scores were spread across seventeen plots in four research sites, namely Negeri Passo, Negeri Lama, Nania and Waiheru village. The plot referred to in this study is the point of mangrove distribution based on NDVI analysis. NDVI values range from 0.26 to 0.57, therefore they can be categorized in medium density (NDVI value $=0.25-0.50$ ) and solid (NDVI value $=0.50-1.00)$. NDVI values greater than 0.50 indicate that mangrove vegetation at some locations in Teluk Ambon Baguala is still relatively healthy and productive because it has a high level of greenery.

Data on the density of mangrove vegetation based on NDVI were then tested for its accuracy using the method developed by Short (1982) in Sutanto (1986) [12]. Samples were chosen based on the distribution and area extent on vegetation density distribution map, i.e 10 polygons. The density test of mangrove vegetation density February in Table 1.

Table 1 exhibits that among 10 samples of polygons, there are 9 true samples and 1 incorrect sample. Based on the calculation, if 9 out of 10 samples are true, accuracy percentage of mangrove vegetation density based on NDVI is $90 \%$. This shows that the result of interpretation of vegetation density based on NDVI has very good accuracy, therefore, it can be used as input in making mangrove vegetation distribution map in Teluk Ambon Baguala district in 2015. Mangrove vegetation density in Teluk Ambon Baguala District 2015 is presented in Figure 1

Table 1. Cross Matrix Density Accuracy Test

\begin{tabular}{|c|c|c|c|}
\hline \multirow{2}{*}{ FDVI } & \multicolumn{3}{|c|}{$\begin{array}{c}\text { Category of Mangrove } \\
\text { Vegetation Density }\end{array}$} \\
\hline & Dense & Medium & Rare \\
\hline Dense & 5 & & \\
\hline Medium & 1 & 4 & \\
\hline Sparse & & & 0 \\
\hline Correct & 5 & 4 & 0 \\
\hline Incorrect & 1 & & \\
\hline
\end{tabular}
Mangrove vegetation based on NDVI

Source: primary data analysis (2017)
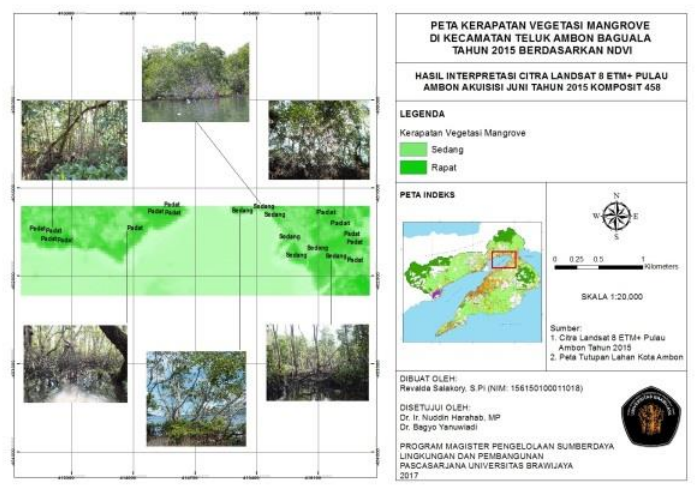

Figure 1. Density Mangrove Vegetation

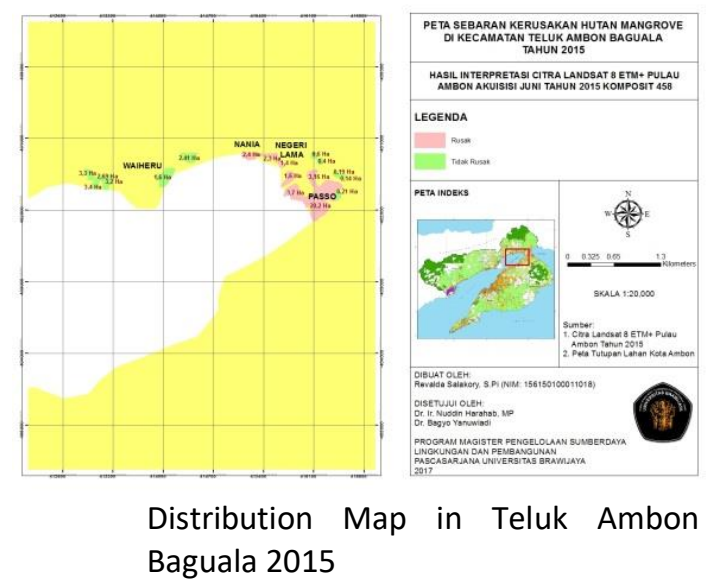

Figure 2. Map Distribution of Mangrove Forest Damage Teluk Ambon Baguala District 2015

Figure 1 shows that District density is more dominant compared to medium density based on the distribution map. It also exhibits mangrove vegetation with solid density spread in 11 plots at 
two research sites which were Negara Passo and Waiheru Village. This indicates that the mangrove forest ecosystem in both locations is categorized not damaged / good. As for the medium density, spread in seven plots in Negeri Passo, Negeri Lama, and Nania village. The mangrove forest ecosystem in these three locations can be categorized as minor damage. The distribution of mangrove forest destruction in Teluk Ambon Baguala district in 2015 is presented in Figure 2.

The area and extent of damage to mangrove forest ecosystem in Teluk Ambon Baguala District 2015 based on Figure 5.2 are explained in Table 2.

Table 2. The area and extent of damage to mangrove forest ecosystem in Teluk Ambon Baguala district 2015

\begin{tabular}{lrrr}
\hline & \multicolumn{2}{c}{$\begin{array}{c}\text { The area and extent of damage to } \\
\text { Research } \\
\text { mangrove forest ecosystem }\end{array}$} \\
\cline { 2 - 4 } & $\begin{array}{c}\text { Undamaged } \\
\text { (Ha) }\end{array}$ & $\begin{array}{c}\text { Light } \\
\text { Damage } \\
\text { (Ha) }\end{array}$ & $\begin{array}{c}\text { Total } \\
\text { (Ha) }\end{array}$ \\
\hline Passo & 0,64 & 28,66 & 29,30 \\
Negeri & 0 & 3,70 & 3,70 \\
Lama & & & \\
Nania & 0 & 2,40 & 2,40 \\
Waiheru & 16,60 & 0 & 16,60 \\
$\quad$ Total & $\mathbf{1 7 , 2 4}$ & $\mathbf{3 4 , 7 6}$ & $\mathbf{5 2 , 0 0}$ \\
\hline
\end{tabular}

Source: primary data analysis (2017)

Table 2 exhibits Waiheru Village possessing mangrove forest with the highest percentage of area for the undamaged (good) category, as much as $16,60 \mathrm{Ha}$. In contrast, the mangrove forest with the highest percentage of area for the light-damaged category was in Negeri Passo, which was $28.66 \mathrm{Ha}$. The destruction of mangrove forests in Passo is related to the high transfer function in this area. This is in accordance with Salampessy et.al (2015) which states that the mangrove forest will be damaged by the conversion of mangrove forest area into a development area [13]. Pattipeilohy (2014) and Asyawati (2015) argue that mangrove forests are generally converted by the government, private and public for residential, recreation and tourism and other physical development areas [14] [15]. The high conversion of mangrove forests in Negeri Passo is related to the establishment as Central Regional Development Unit II based on the Ambon City Ranperda (Ranperda) in 2013, which triggered an increase in population and land needs in the surrounding area [16].

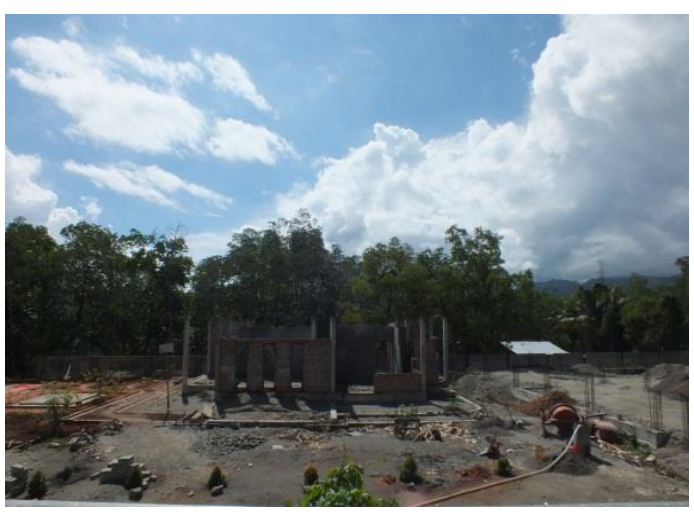

Figure 2. Mangrove forest conversion into the development area

Source: Field photography (2017)

In addition, the destruction of mangrove forests is also caused by sedimentation. Excessive sedimentation can result in death in some species of mangroves (Avicennia sp. And Sonneratia $s p$.) due to respiratory root depletion (pneumothorax) [17]. According to Pelasula (2008), sedimentation in the coastal area of Ambon City occurs as a result of land clearing by converting green land for settlement development without any damage mitigation to the land below it. Pelasula also revealed that the sedimentation in the coastal area of Negeri Passo stems from land clearing activity for the development of "Bukit Lateri Indah" Settlement Area [18]. Based on LIPI Ambon (2015) monitoring, the sediment thickness rate has increased by about $3 \mathrm{~cm}$ per year.

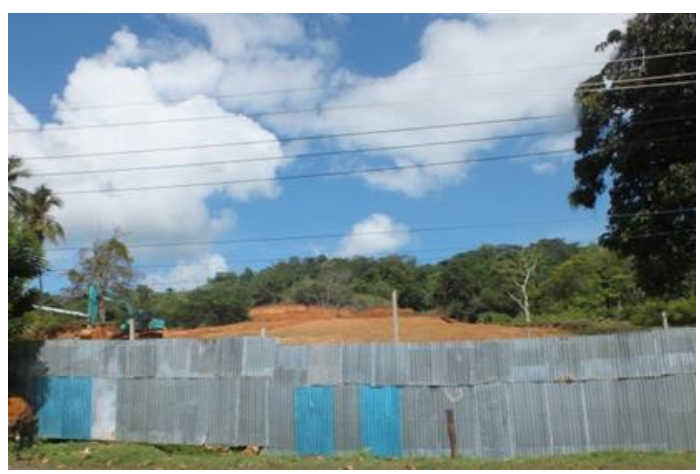

Figure 3. Land clearing for the settlement area Source: field photography (2017)

Another factor related to mangrove forest destruction is water pollution in Teluk Ambon Dalam (TAD). The dominant pollutant loads entering $T A D$ waters are $C O D, T O M$, and BOD. 
The contents of pollutant load COD indicate the presence of pollutants with levels of $\mathrm{NO}_{3}$ and $\mathrm{PO}_{4}$ that have exceeded established standard. This indicates a load of organic waste from the river to sea has exceeded the assimilation capacity of TAD [19]. Such conditions can lead to changes in environmental quality. Based on the results of Zhang et al (2014) study, the pollutant load entry into the waters can decrease dissolved oxygen levels that are highly needed by marine biota for respiration process. Dissolved oxygen content decrease in the waters directly affects the existence and survival of marine life [20]. In addition, another direct impact of mangrove vegetation contamination is the inhibition of respiration process due to the depletion of the respiratory root (pneumatophore) caused by waste resulting in mangrove trees death. Ohello (2010) states that the status of waters in TAD is classified as moderate [21]. Pollution in TAD is caused by sea transport activities (ferries) that produce oil waste, steam power plants and residential settlements around the coast and river banks that produce domestic waste both organic and inorganic.

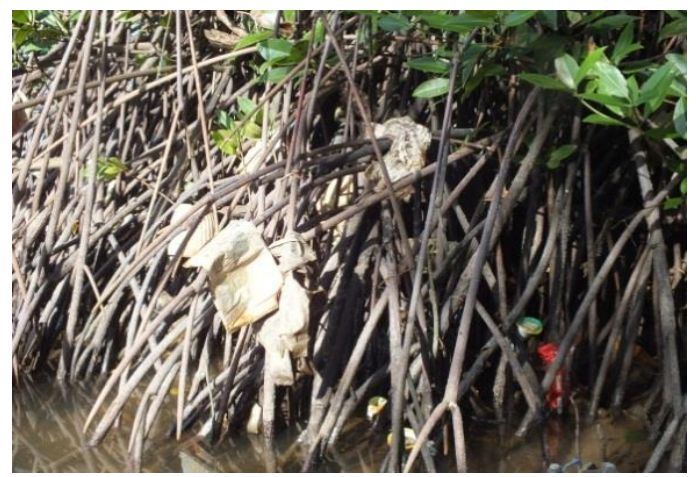

Figure 4. Domestic Waste from Settlement Around Ambon Bay Coast

Economic Value of Mangrove Forest Ecosystem Damage in Teluk Ambon Baguala District

Ecosystem damage's economic value is the total value of mangrove forest ecosystem services lost (in the value of rupiah per year) due to damage in Teluk Ambon Baguala district. Ecosystem damage's economic value is expressed in the present value (2015) and for the next 10 years, in which the mangrove forest ecosystem is expected to recover as or near its original state before the damage occurs. The indicators used in estimating ecosystem damage's economic value are the extent of damage and the total economic value of the mangrove forest ecosystem. Based on the results of NDVI analysis, it is known that mangrove forest ecosystem in Negeri Passo, Negeri Lama, and Nania village has medium vegetation density level and classified as lightly damaged, respectively $28,66 \mathrm{Ha}, 3,70 \mathrm{Ha}$ and $2,40 \mathrm{Ha}$ in 2015. Furthermore, the economic value of mangrove forest ecosystem destruction in Teluk Ambon Baguala in 2015 can be explained in Tables 3 and 4.

Table 3. Economic Value of Mangrove Forest Ecosystem Damage in Ambon Bay Baguala District 2015

\begin{tabular}{lcr}
\hline $\begin{array}{l}\text { Research } \\
\text { Location }\end{array}$ & $\begin{array}{c}\text { Total Economic } \\
\text { Value } \\
\text { (Rp/Ha/ } \\
\text { Year) }\end{array}$ & $\begin{array}{c}\text { Economic Value } \\
\text { of Damage } \\
\text { (Rp/Year) }\end{array}$ \\
\hline Passo & 131.672 .600 & 3.765 .838 .300 \\
N. Lama & 255.575 .100 & 945.627 .800 \\
Nania & 271.146 .000 & 650.750 .400 \\
Total & $\mathbf{1 0 9 . 5 6 8 . 3 0 0}$ & $\mathbf{3 . 8 0 8 . 5 9 4 . 1 0 0}$ \\
\hline
\end{tabular}

Source: primary data analysis (2017)

Table 3 shows that Negeri Passo has the highest mangrove forest ecosystem economic value compared to Negeri Lama and Nania village, which is Rp. 3,765,838,300 per year. The high damage of mangrove forest ecosystems was caused by the conversion of mangrove forest into the development area, sedimentation due to land clearing and pollution. This is in accordance with Rahman et al (2013) study which states that the destruction of mangrove forests is the trigger of mangrove forest function decline as a nursery ground [22]. Harahab (2009) explains that the reduced of nursery ground as the impact of the decline of mangrove forest area, can affecting fish and shrimp production [23].

Table 4. Economic Value of Mangrove Forest Ecosystem Damage in Teluk Ambon Baguala District During 10 Years of Recovery

\begin{tabular}{lcc}
\hline $\begin{array}{l}\text { Research } \\
\text { Location }\end{array}$ & $\begin{array}{c}\text { Economic Value of } \\
\text { Damage in } \\
\mathbf{2 0 1 5} \\
\text { (Rp/vear) }\end{array}$ & $\begin{array}{c}\text { Economic Value of } \\
\text { Damage for 10 years } \\
\text { (Rp/year) }\end{array}$ \\
\hline Passo & 3.765 .838 .300 & 209.213 .200 \\
N. Lama & 945.627 .800 & 52.534 .800 \\
Nania & 650.750 .400 & 36.152 .800 \\
Total & $\mathbf{3 . 8 0 8 . 5 9 4 . 1 0 0}$ & $\mathbf{2 9 7 . 9 0 0 . 8 0 0}$ \\
Average & $\mathbf{9 5 2 . 1 4 8 . 5 0 0}$ & $\mathbf{7 4 . 4 7 5 . 2 0 0}$ \\
\hline
\end{tabular}

Source: primary data analysis (2017) 
Table 4 exhibits the economic value of ecosystem services lost since mangrove forest ecosystem destruction occurred in 2015 until it recovers as or near the previous condition which amounts to Rp. $297,900,800$ with an annual discount rate of $8 \%$. The economic value of mangrove forest ecosystem damage during 10 years period are as follows: Negeri Passo Rp. 209,213,200 per year, Negeri Lama village for Rp. $52,534,800$ per year and Nania Village for Rp. $36,152,800$ per year.

Table 4 also exhibits the economic value of mangrove forest ecosystem destruction in Teluk Ambon Baguala district has decreased every year along with ecosystem recovery. For that, it takes conservation efforts to minimize the economic value of mangrove forest ecosystem destruction in Ambon Bay Ambon Baguala.

\section{CONCLUSION}

Mangrove forests in Teluk Ambon Baguala in 2015 are categorized not damaged $(17.24 \mathrm{Ha})$ and lightly damaged (34.76 $\mathrm{Ha}$ ). Waiheru village has mangrove forest with the highest percentage of area for the undamaged (good) category, for $16,60 \mathrm{Ha}$. In contrast, the mangrove forest with the highest percentage of area for the lightdamaged category was in Negeri Passo, which was $28.66 \mathrm{Ha}$. Overall, the economic value of ecosystem services lost due to mangrove forest destruction in Teluk Ambon Baguala district is Rp. 3.808.594.100 per year. Negeri Passo for Rp. $3,765,838,300$ per year, Negeri Lama Village for Rp. 945.627.800 per year and Nania Village for Rp. $650,750,400$ per year.

One of the causes of damage to mangrove forest ecosystems in Teluk Ambon Baguala is water pollution caused by domestic and industrial waste. Thus, it is necessary to apply Pigovian taxes (i.e environmental taxes devoted to activities that generate negative externalities) in Ambon Regional Regulations as a policy and legal product capable of supporting the conservation of mangrove forest ecosystems and control pollution in Ambon Bay waters, with reference to economic value damage to mangrove forest ecosystems.

\section{ACKNOWLEDGMENT}

In relation to the completion of this writing, the authors extend their appreciation and gratitude to the parties who have provided assistance, both substantially and financially. Without the opportunity, guidance, input and spirit support from CPC / mother, of course, this writing will not be realized as it is today. May Allah SWT always delegate His Grace and His Gift to us all in carrying out the devotion to the glory of our beloved country and nation. Amen.

\section{REFERENCES}

[1] Dahuri, Rokhmin dan Rais, Jacub dan Ginting, Sapta, P. dan Sitepu, M., J., 2008. Pengelolaan Sumber Daya Wilayah Pesisir dan Lautan Secara Terpadu. Jakarta: PT. Pradnya Paramita

[2] Uddin, Md., Shams dan van Steveninch E., de Ruyter dan Stuip, Mishka dan Shah, Mohammad, A., R., 2013. Economic Valuation of Provisioning and Cultural Services of Protected Mangrove Ecosystem. Ecosystem Services 5: e88-e93

[3] Purnobasuki, Hery, 2011. Ancaman Terhadap Hutan Mangrove di Indonesia dan Langkah Strategis Pencegahannya. Buletin PSL Universitas Surabaya 25: 3-6

[4] Suyadi, 2009. Kondisi Hutan Mangrove di Teluk Ambon: Prospek dan Tantangan. Berita Biologi 5: 481-490

[5] Madiama, Saptono dan Muryani, Chatarina dan Santoso, Sigit, 2016. Kajian Perubahan Luas dan Pemanfaatan serta Persepsi Masyarakat Terhadap Pelestarian Hutan Mangrove di Teluk Ambon Baguala. Jurnal GeoEco 2: 170-183

[6] Ahmad, Nuril dan Yanuwiadi, Bagyo dan Soemarno, 2012. Adaptasi Ekologi dan Persepsi Masyarakat Pesisir Dalam Upaya Konservasi Mangrove di Dusun klayar Desa Sidokelar Kecamatan Pacitan Kabupatem Lamongan. Wacana 3: 29-36

[7] Admiraal, Jeroen, F. dan Wossink, Ada dan de Groot,Wouter, T dan de Snoo, Geert, R., 2013. More Than Total Economics: How To Combine Economic Valuation of Biodiversity with Ecological Resilience. Ecological Economics 89: 115-122

[8] Harahab, Nuddin, 2010. Pemetaan Hutan Mangrove serta Nilai Ekonomi Barang dan Jasa Lingkungan yang Dihasilkan. Jurnal Kehutanan Tropika 3: 183-191

[9] Lee, Tsai-Ming dan Yeh, Hui-Chung, 2009. Applying Remote Sensing Techniques To Monitor Shifthing Wetland Vegetation: A Case Studi of Danshui River Estuary Mangrove Communities, Taiwan. Ecological Engineering 35: 487-496

[10] Harahab, Nuddin, 2010. Penilaian Ekonomi Ekosistem Hutan Mangrove dan Aplikasinya 
Dalam Perencanaan Wilayah. Yogyakarta: Graha IImu

[11] Suparmoko, M. dan Sudirman, Dadang dan Setyanko dan Wibowo, Haryo., 2014. Valuasi Ekonomi Sumber Daya Alam dan Lingkungan. Yogyakarta: BPFE-Yogyakarta

[12] Sutanto, 1997. Penginderaan Jauh dan Sistem Informasi Geografis Perkembangan Mutakhir dan Terapannya. Mimeo, makalah disampaikan pada Seminar Nasional Penginderaan Jauh untuk Kesehatan Pemantauan dan Pengendalian Penyakit Terkait Lingkungan, Fakultas Kedokteran Universitas Gadjah Mada

[13] Salampessy, M. L. dan papilaya, R. 2015. Cultural Capital of The Communities in The Mangrove Area of ambon dalam Bay, Mollucas, Indonesia. Procedia Environmental Sciences 23: 222-229

[14] Pattipeilohy, Mery, 2014. Fenomena Pendangkalan Zona Pasang Surut Hutan Mangrove Teluk Dalam Ambon serta Upaya Pengembangan Ekowisata. Jurnal Pena Sains 1: 56-63

[15] Asyiawati, Yulia, 2015. Pengaruh Pemanfaatan Lahan Terhadap Ekosistem Pesisir di Kawasan Teluk Ambon. Jurnal Perencanaan Wilayah dan Kota (tanpa nomor): 15-19

[16] Haumahu, J. P., 2014. Analisis Perubahan Penggunaan Lahan Jazirah Leitimur Pulau Ambon. Jurnal Ilmu Budidaya Tanaman 3: 103-111

[17] Zamprogno, Gabriela, Carvalho dan Tognella, Monica, Maria, Pereira dan da Silva Quaresma, Valeria dan da Costa, Mercia, Barcellos dan Pascoalini, Savia, Soares dan do Couto, Ger Facco, 2016. The Structural Heterogeneity of an Urbanized Mangrove Forest Area in Southeastern Brazil: Influence of Environmental Factore and Anthropogenic Stressors. Brazilian Journal of Oceanography 64: 1-7

[18] Pelasula, Daniel, Deonisius, 2008. Dampak Perubahan Lahan Atas Terhadap Ekosistem Pesisir Teluk Ambon. Tesis Magister Sains, Program Pascasarjana Universitas Pattimura, Ambon

[19] Selanno, Debby, Amelia, Jemima, 2009. Analisis Hubungan Antara Beban Pencemaran dan Konsentrasi Limbah Sebagai Dasar Pengelolaan Kualitas Perairan Teluk Ambon Dalam. Abstrak Disertasi Doktor, Program Pascasarjana Institut Pertanian Bogor, Bogor
[20] Zhang, Zai-Wang dan xu, Xiang-Rong dan Sun, Yu-Xin dan Yu, Shen dan Cheng, YongShan dan Peng, Jia-Xi, 2014. Heavy Metal and Organic Contaminants in Mangrove Ecosystems of China: a Review. Environmental Science and Pollution Research 23: 11.938-11.950

[21] Ohello, Marselitha, Trivena, 2010. Kondisi Lingkungan Perairan Teluk Ambon Dalam dan Hubungannya Dengan Perilaku Masyarakat. Tesis Magister Sains, Program Pascasarjana Institut Pertanian Bogor, Bogor

[22] Rahman, Abdullah, F. dan Dragoni, Danilo dan Didan, Kamel dan barreto-muno, Armando dan hutabarat, Joseph, A., 2013. Detecting Large Scale Conversion of Mangrove to Aquaculture with Change Point and Mixed Pixel Analyses of Highfidelity MODIS Data. Remote Sensing of Environment 130: 96-107

[23] Harahab, Nuddin, 2009. Pengaruh ekosistem Hutan Mangrove Terhadap Produksi Perikanan Tangkap (Studi Kasus di Kabupaten Pasuruan, Jawa Timur). Jurnal Perikanan (J.Fish.Sci) 9; 100-106 